\title{
QUANTITY OF ANTIBIOTIC USE AND RESISTANCE PATTERN OF GUT NORMAL FLORA Escherichia coli AT INTENSIVE CARE UNIT AND TROPIC INFECTION WARD, DR. SOETOMO HOSPITAL, SURABAYA, INDONESIA
}

\author{
Mohammad Akbaruddin Sholeh ${ }^{1}$, Kuntaman Kuntaman ${ }^{2}$, Usman Hadi ${ }^{3}$ \\ ${ }^{1}$ Master Program of Basic Medical Science, Universitas Airlangga /Department of Microbiology, Sultan Agung \\ University, Semarang, ${ }^{2}$ Department of Clinical Microbiology, ${ }^{3}$ Department of Internal Medicine, Dr. Soetomo \\ Hospital/Faculty of Medicine, Universitas Airlangga, Surabaya, Indonesia
}

\section{ABSTRACT}

This study aimed to analyze the relationship of the quantity of antibiotic use with the pattern of resistance of gut normal flora Escherichia coli among patients in Intensive Care Unit (ICU) and Tropic Infection Ward, Dr. Soetomo Hospital, Surabaya. This study was cross-sectional design with 64 samples (32 the ICU and 32 in Tropic Infection Ward). The total sample were collected for three Months. Identification of intestinal microflora was done with McConkey differential selective medium, followed by IMViC biochemical test, and sensitivity test by antibiotic disc diffusion method. Data were analyzed with Chi square test and Fisher's Exact test. There was no significant difference $(p=0.441)$ in the quantity of antibiotic use between ICU and Tropic Infection Ward. There was no significant difference $(p>0.05)$ in normal intestinal flora Escherichia coli resistance pattern between Tropic Infection Ward and ICU against 12 types of antibiotics. The highest percentage of intestinal flora Escherichia coli resistance at the ICU was ceftriaxone as many as 18 (56.3\%) and at Tropic Infection Ward on ciprofloxacin and levofloxacin 20 (62.5\%). The other study in Primary Health center, showed that the resistance rates of both wards were significantly different as compared to intestinal flora of patients in primary health center ( $p<0.001)$, in which the use of antibiotics in primary health center was also lower (1.6 DDD). There was no significant difference ( $p>0.05)$ The pattern of bacterial resistance between patient with and without antibiotic use at Tropic Infection Ward and ICU. The quantity of antibiotic use was not significantly different against resistnt gut flora between patients in ICU and Tropic Infection ward. The pattern of bacterial resistance between patient with and without antibiotic use was also not significantly different.

Keywords: Antibiotic; antimicrobial resistance; hospitalized patients

\section{ABSTRAK}

Penelitian ini bertujuan untuk menganalisis hubungan kuantitas penggunaan antibiotik dengan pola resistensi Escherichia coli flora normal usus pada pasien di ruang rawat intensif dan ruang rawat tropik infeksi RSUD Dr.Soetomo Surabaya. Metode penelitian ini menggunakan desain cross-sectional dengan sampel sebanyak 64 (32 di ruang rawat intensif dan 32 di ruang tropis infeksi). Tehnik pengambilan sampel menggunakan total populasi selama tiga bulan. Identifikasi mikroflora usus dilakukan dengan menanam pada medium selektif diferensial McConkey, dilanjutkan uji biokimia IMViC, dan uji sensitifitas dengan metode difusi cakram. Data dianalisis menggunakan uji Chi square atau uji Fisher's Exact. Tidak terdapat perbedaan bermakna $(p=0,441)$ kuantitas penggunaan antibiotik antara ruang rawat inap intensif dengan ruang tropik infeksi. Tidak terdapat perbedaan bermakna $(p>0,05)$ pola resistensi Escherichia coli flora normal usus antara ruang tropik infeksi dan ruang rawat intensif terhadap 12 jenis antibiotik. Persentase tertinggi Escherichia coli flora normal usus yang resisten di ruang rawat intensif adalah seftriakson sebanyak 18 (56,3\%), dan di ruang tropik infeksi adalah siprofloksasin dan levofloksasin sebanyak 20 (62,5\%). Jika dibanding dengan peneliti lain di puskesmas, pola resistensi di kedua ruang tersebut berbeda bermakna dibanding pola resistensi flora usus pasien di Puskesmas ( $p<0,001)$, dimana penggunaan antibiotika di Puskesmas lebih rendah (1,6 DDD). Tidak terdapat perbedaan bermakna $(p>0,05)$ perbandingan pola resistensi antara yang menggunakan dan yang tidak menggunakan antibiotik di ruang tropik infeksi dan ruang rawat intensif. Kesimpulan: Kuantitas penggunaan antibiotika di ruang ICU dan ruang Tropik Infeksi tidak berbeda bermakna, yang disertai juga dengan pola resistensi terhadap antimikroba yang tidak ada perbedaan di antara kedua ruang tersebut. Perbandingan pola resistensi antara yang menggunakan dan yang tidak menggunakan antibiotika, di ICU dan di Tropik Infeksi tidak berbeda bermakna.

Kata kunci: Antibiotik; resistensi antimikroba; pasien rawat inap

Correspondence: K. Kuntaman, Microbiology Department, Faculty of Medicine, Universitas Airlangga, Surabaya. E-mail: k.kuntaman@fk.unair.ac.id 


\section{INTRODUCTION}

Resistance to antibiotics is the worldwide problems in health services (WHO, 2012). Therefore, WHO establishes several strategies, including efforts to use rational antibiotics, reduce selective pressure by changing antibiotic prescribing behavior, and make antibiotic resistance as a problem for every country in Southeast Asia (WHO SEARO, 2010). The use of antibiotics plays a role in the emergence of antimicrobial resistance through selective pressure. All individuals receiving a dose of antibiotic therapy will impact on changes in the normal floral microbial population, either in the intestinal, respiratory or genitourinary tracts (Brunton et al, 2011; Penders, 2013). The use of antibiotics as a drug in bacterial infections is often inappropriate, causing problems and threats to health, especially bacterial resistance to antibiotics (Bruinsma, 2003). One of those resistance bacteria is normal flora of the E. coli in gastrointestinal tract. Based on the results of Antimicrobial Resistant in Indonesia: Prevalence and Prevention (AMRIN-study) study from 2000-2004. In the community group of 2996 individual, 2494 information cases regarding carriage of Escherichia coli, $43 \%$ of whom were resistant to various antibiotics such as ampicillin $34 \%$, cotrimoxazole $29 \%$, and chloramphenicol $25 \%$. Whereas, among 781 hospitalized patients, the level of $E$. coli resistance on ampicillin was $73 \%$, cotrimoxazole $56 \%$, chloramphenicol $43 \%$, ciprofloxacin $22 \%$ and gentamicin $18 \%$.

The use of antibiotics against pathogenic bacteria directly or indirectly affects the resistance of normal commensal bacterial flora in the body, including the gastrointestinal tract (Elaa et al., 2016). The percentage of people who colonized by faecal Escherichia coli microflora resistant to ampicillin and cephalotin showed significant increase when the patient came out of ICU or the hospital and remained unchanged for 3 months after discharge from the hospital. The frequency of this resistance will increase significantly in patients with longer hospitalization in intensive care (Duerink et al., 2007).

The aims of this study was to determine the quantity of antibiotic usage and its correlation with normal commensal micro-flora resistance in the patient's gastrointestinal tract at ICU and Tropic Infection Ward at Dr. Soetomo Hospital, Surabaya.

\section{MATERIALS AND METHODS}

This study was cross-sectional design to determine the difference of quantity of antibiotic usage with resistance pattern of intestine normal flora Escherichia coli in patients at the ICU and Tropic Infection Ward, Dr. Soetomo Hospital, Surabaya. The samples were patients' data from medical record and rectal swab taken from patient at ICU and Tropical Infection Ward, Dr Soetomo Hospital. The total 64 samples (32 in ICU and 32 in Tropical Infection Ward) were collected. Samples were taken with consecutive sampling, including all ICU and Tropical Infection Ward according to the inclusion criteria, between April - July 2017. The inclusion criteria were all patients at ICU and Tropical Infection Ward, Dr. Soetomo Hospital, Surabaya, with length of hospitalization $\geq 5$ days, and willing to take part in this study after giving information for consent.

Identification of intestinal micro-flora (Escherichia coli) was performed using Mc Conkey's differential selective medium, then continued with IMViC (Indol, Methyl Red, Voges Proskauer, Citrate) biochemical test. Sensitivity test was conducted by disc diffusion method referred to CLSI 2016. Measurement of the quantity of antibiotic use was done by Define Daily Dose (DDD) system with the classification based on Anatomical Therapeutic Chemical Classification (ATC) and measurement of antibiotic usage with defined daily dose (DDD)/100 patient days.

Rectal swab specimens were grown on McConkey medium. The suspected $E$. coli will growth with lactose fermenter and pink colony. Identification was performed using IMViC Test (Indol test, Metyl red, Voges-Proskauer, citrate). Escherichia coli will show in this test $(+,+,-,-)$. The identified gut flora, Escherichia coli, were then tested of susceptibility against antibiotics as follow:Amoxicillin-Clavulanic acid (20/10 ug); piperacillin-tazobactam $(100 / 10 \mu \mathrm{g})$; ceftazidime $(30$ $\mu \mathrm{g})$; ceftriaxone (30 $\mu \mathrm{g})$; ciprofloxacin $(5 \mu \mathrm{g})$; levofloxacin $(5 \mu \mathrm{g})$; amikacin $(30 \mu \mathrm{g}$; fosfomycin $(200$ $\mu \mathrm{g})$; cefoperazon-sulbactam $(75 / 30 \mu \mathrm{g})$; meropenem (10 $\mu \mathrm{g})$; tigecycline $(15 \mu \mathrm{g})$; and cefotaxim $(30 \mu \mathrm{g})$, then incubated for 16-18 hours. After incubation overnight, the inhibition zone was measured as standard of CLSI (2016). The data was analyzed using SPSS-20.

\section{RESULTS}

The total samples were collected, 32 samples from each of wards, ICU and Tropical Infection ward. The patients in Tropic Infection Ward there were $5(15.63 \%)$ males and $27(84.37 \%)$ females whereas in ICU $20(62.5 \%)$ males and $12(37.5 \%)$ females. The age, there were 1 children (aged 2-11 years), 15 adolescents (12-25 year), 10 adults (aged 26-45 years), and 38 elderly (aged 46-80 years). Most of the samples at Tropic Infection Ward were elderly $(62.5 \%)$, and at the ICU $(56.25 \%)$. Patients 
from Tropic Infection Ward who consumed antibiotics were $13(40.6 \%)$, and those who did not use antibiotics were $19(59.4 \%)$ whereas in ICU who consumed antibiotics were $10(31,25 \%)$, and did not use antibiotics as many as $20(68.75 \%)$.

Data analysis showed that the highest quantity of antibiotic use, of both in Tropic Infection Ward and the ICU, was ceftriaxone. However, the quantity of ceftriaxone use in ICU was higher, with 100 DDD or 39.37 DDD/100 patient days compared to that in Tropic Infection Ward with 54 DDD or 21.51 DDD/100 patient days. The lowest quantity of antibiotic use in Tropic Infection Ward was cefixime of 1.5 DDD or 0.59 DDD/100 patient days, whereas, the lowest quantity of antibiotic use in the ICU was cefoperazone-sulbactam of 2.25 DDD or 0.08 DDD/100 patient days.

The results showed that the quantity of antibiotic in Tropic Infection Ward and the ICU were 137.75 and $180.17 \mathrm{DDD}$, or 54.86 and $68.56 \mathrm{DDD} / 100$ patient days. Data pattern of resistance of normal intestinal flora Escherichia coli isolated from 32 patients in Tropic Infection Ward showed as follow: ciprofloxacin
$62.5 \%$; levofloxacin 62.5\%; ceftriaxone $43.3 \%$; cefotaxime $37.5 \%$; ceftazidim $34.4 \%$; amoxicillinclavulanic acid $21.9 \%$; Fosfomycin $6.3 \%$; cefoperazonsulbactam $3.1 \%$; amikacin $3.1 \%$; and meropenem $3.1 \%$. Resistance of normal intestinal flora Escherichia coli isolated from 32 patients in the ICU showed a high percentage of resistance as follow: ceftriaxone 56.3\%; ciprofloxacin 53.1\%; cefotaxime 50\%; levofloxacin $50 \%$; ceftazidim 28.1\%; amoxicillin-clavulanic acid $21.9 \%$; cefoperazon-sulbactam $6.3 \%$; amikacin $6.3 \%$; tygecycline $6.3 \%$; Fosfomycin $6.3 \%$, meropenem $3.1 \%$; and piperacilin-tazobactam $3.1 \%$.

The quantity of antibiotic use between Tropic Infection Ward and ICU showed no significant difference $(\mathrm{p}=0.441)$ indicating that the quantity of antibiotic use in both sites was similar. The normal flora intestinal Escherichia coli resistance pattern between Tropic Infection Ward and ICU also showed no significant difference ( $p>0.05$ ) against 12 antibiotic types. The resistance pattern of $E$. coli was not significant correlation with antibiotic use (p>0.05) against 12 antibiotic types.

Table 1. Comparison of quantity antibiotic use (in DDD) at Tropic Infection Ward and ICU, Dr. Soetomo Hopsital, Surabaya

\begin{tabular}{ccccc}
\hline Total DDD & $\mathrm{N}$ & Mean \pm s.b. & Mean difference (IK95\%) & $\mathrm{P}$ \\
\hline ICU & 32 & $4.3 \pm 4.59$ & $1.32(1.38-4.03)$ & 0.441 \\
Tropic Ward & 32 & $5.6 \pm 6.12$ & \\
\hline
\end{tabular}

Note: DDD=Define Daily Dose; $\mathrm{N}=$ number of sample; $\mathrm{p}$ :significant value

Table 2. Comparison of resistance pattern of E. coli at Tropic Infection Ward and ICU, Dr. Soetomo Hospital, Surabaya

\begin{tabular}{|c|c|c|c|c|c|}
\hline \multirow{3}{*}{ Antibiotic } & \multicolumn{4}{|c|}{ Groups } & \multirow{3}{*}{$\mathbf{p}$} \\
\hline & \multicolumn{2}{|c|}{ Tropic Ward } & \multicolumn{2}{|c|}{ ICU } & \\
\hline & $\mathrm{N}(32)$ & $\%$ & $\mathrm{~N}(32)$ & $\%$ & \\
\hline AK Resistance & 1 & 3.1 & 2 & 6.3 & 1.000 \\
\hline AMC Resistance & 7 & 21.9 & 7 & 21.9 & 1.000 \\
\hline SCF Resistance & 1 & 3.1 & 2 & 6.3 & 1.000 \\
\hline CTX Resistance & 12 & 37.5 & 16 & 50 & 0.313 \\
\hline CAZ Resistance & 11 & 34.4 & 9 & 29.1 & 0.590 \\
\hline CRO Resistance & 14 & 43.8 & 18 & 56.3 & 0.317 \\
\hline CIP Resistance & 20 & 62.5 & 17 & 53.1 & 0.448 \\
\hline FOS Resistance & 2 & 6.3 & 2 & 6.3 & 1.000 \\
\hline LEV Resistance & 20 & 62.5 & 16 & 50 & 0.313 \\
\hline MEM Resistance & 1 & 3.1 & 1 & 3.1 & 1.000 \\
\hline TZP Resistance & 0 & 0 & 1 & 3.1 & 1.000 \\
\hline TGC Resistance & 0 & 0 & 2 & 6.3 & 0.492 \\
\hline
\end{tabular}


Table 3. The pattern of resistance of E. coli, between the patient with antibiotic use and patient without antibiotic use. at Tropic Infection Ward and ICU Dr. Soetomo Hopsital, Surabaya

\begin{tabular}{|c|c|c|c|c|c|c|c|c|}
\hline \multirow{3}{*}{\multicolumn{2}{|c|}{ Antibiotic Use }} & \multicolumn{3}{|c|}{ Tropic Ward } & \multicolumn{3}{|c|}{ ICU } & \multirow{3}{*}{$\mathrm{P}$} \\
\hline & & \multicolumn{2}{|c|}{ Resistance } & \multirow[b]{2}{*}{$\mathrm{p}$} & \multicolumn{2}{|c|}{ Resistance } & \multirow[b]{2}{*}{$\mathrm{p}$} & \\
\hline & & $(+)$ & $(-)$ & & $(+)$ & $(-)$ & & \\
\hline \multirow{2}{*}{ AK } & $(+)$ & 1 & 21 & \multirow{2}{*}{1.000} & 0 & 19 & \multirow{2}{*}{0.157} & \multirow{2}{*}{0.291} \\
\hline & $(-)$ & 0 & 10 & & 2 & 11 & & \\
\hline \multirow{2}{*}{ AMC } & $(+)$ & 5 & 17 & \multirow{2}{*}{1.000} & 3 & 16 & \multirow{2}{*}{0.401} & \multirow[b]{2}{*}{1.000} \\
\hline & $(-)$ & 2 & 8 & & 4 & 9 & & \\
\hline \multirow{2}{*}{ SCF } & $(+)$ & 1 & 21 & \multirow{2}{*}{1.000} & 1 & 18 & \multirow{2}{*}{1.000} & \multirow{2}{*}{1.000} \\
\hline & $(-)$ & 0 & 10 & & 1 & 12 & & \\
\hline \multirow{2}{*}{ CTX } & $(+)$ & 8 & 14 & \multirow{2}{*}{1.000} & 10 & 9 & \multirow{2}{*}{1.000} & \multirow{2}{*}{0.780} \\
\hline & $(-)$ & 4 & 6 & & 6 & 7 & & \\
\hline \multirow[b]{2}{*}{$\mathrm{AZ}$} & $(+)$ & 6 & 16 & \multirow{2}{*}{0.252} & 6 & 13 & \multirow{2}{*}{0.704} & \multirow{2}{*}{0.297} \\
\hline & $(-)$ & 5 & 5 & & 3 & 10 & & \\
\hline \multirow{2}{*}{$\mathrm{CRO}$} & $(+)$ & 8 & 14 & \multirow{2}{*}{0.267} & 10 & 9 & \multirow{2}{*}{0.725} & 1000 \\
\hline & $(-)$ & 6 & 4 & & 8 & 5 & & 1.000 \\
\hline CIP & $(+)$ & 13 & 9 & 0.703 & 11 & 8 & 0.720 & 0.128 \\
\hline CIP & $(-)$ & 7 & 3 & 0.103 & 6 & 7 & 0.120 & 0.120 \\
\hline FOS & $(+)$ & 1 & 21 & 0534 & 0 & 19 & 0157 & 0793 \\
\hline 3 & $(-)$ & 1 & 9 & 0.034 & 2 & 11 & ול & 0.190 \\
\hline & $(+)$ & 13 & 9 & & 11 & 8 & & \\
\hline LEV & $(-)$ & 7 & 3 & 0.103 & 5 & 8 & $0.4 / 3$ & 1.000 \\
\hline MFM & $(+)$ & 1 & 21 & 1000 & 0 & 19 & 0406 & 1000 \\
\hline RIEIVI & $(-)$ & 0 & 10 & 1.000 & 1 & 12 & 0.400 & 1.000 \\
\hline T7P & $(+)$ & 0 & 22 & 1000 & 0 & 19 & 0406 & 1000 \\
\hline $12 \mathrm{P}$ & $(-)$ & 0 & 10 & 1.000 & 1 & 12 & 0.400 & 1.000 \\
\hline TGC & $(+)$ & 0 & 22 & 1000 & 1 & 18 & 1000 & 1000 \\
\hline $1 \mathrm{GC}$ & $(-)$ & 0 & 10 & 1.000 & 1 & 12 & 1.000 & 1.000 \\
\hline
\end{tabular}

The pattern of bacterial resistance against 12 antibiotic types between the patient with antibiotic use and without use antibiotic at Tropic Infection Ward and ICU was not significant difference ( $p>0.05)$.

\section{DISCUSSION}

Antibiotics mostly used in the ICU was ceftriaxone of 100 DDD or 39.37 DDD/100 patient days, while the lowest was cefoperazon-sulbactam with 2.25 DDD or $0.88 \mathrm{DDD} / 100$ patient days. Antibiotics mostly used in Tropic Infection Ward was ceftriaxone as much as 54 DDD or $21.51 \mathrm{DDD} / 100$ patient days, while the lowest was cefixime with $1.5 \mathrm{DDD}$ or $0.59 \mathrm{DDD} / 100$ patient days. Total use of antibiotics in Tropic Infection Ward was 137.75 DDD or $54.86 \mathrm{DDD} / 100$ patient days, and in ICU as much as $180.17 \mathrm{DDD}$ or $68.56 \mathrm{DDD} / 100$ patient days. There was no significant difference $(\mathrm{p}=0.441)$.

The highest percentage of resistant intestinal normal flora Escherichia coli in ICU was against ceftriaxone as many as $18(56.3 \%)$. whereas the highest use of antibiotic in ICU was ceftriaxone. It has been recognized that cefotaxime, ceftazidim, and cefoperazone - sulbactam have the same core structure $\beta$-lactam ring with ceftriaxon that allows cross resistance against the three tested antibiotics (Kuntaman et al., 2005). The emergence of resistance in nosocomial pathogens has been shown to be associated with antibiotic misuse (overuse and inappropriate use) in therapy and prophylaxis. Antibiotics use is the most important factor causing resistance development (Hadi, 2009; Barbosa, 2017). Co-selection is one of the reasons for why it is difficult to reverse resistance once it has been established in a bacterial population. It is simply not enough to stop using one particular antibiotic if the resistance mechanisms is linked to resistance for other antibiotics (Wales, 2015). Co-selection process through maintenance of resistance to a particular antibiotic, even if its use has been discontinued. Multiple resistance genes are frequently found on the same plasmid or transposon and therefore the use of any of the antibiotics would select for resistance to all the others (Barbosa, 2017).The highest percentage of resistant 
intestinal normal flora Escherichia coli at Tropic Infection Ward against ciprofloxacin and levofloxacin was 20 (62.5\%). Previous study (Arce et al. 2011) also showed similar results. A study by Arce et al (2011) also showed that the levels of antimicrobial resistance were higher among hospitalized patients' isolates than among community isolates, illustrating the higher antimicrobial pressure that enhances the selection for resistant strains and the transmission of resistance mechanism. The higher use of ciprofloxacin would be due to its available in both of oral and parenteral form, beside its broad spectrum activity (Pedrera $\mathrm{V}$ et al. 2004, Arce et al. 2011).

The resistance pattern of 64 samples, E. coli were mostly sensitive to piperacillin-tazobactam, amikacin, cefoperazon-sulbactam and fosfomycin. A study by Arce et al (2011) also showed similar results. This is possible because amikacin and fosfomycin are potent antibiotics with narrow spectrum activity, that used only in hospital setting, so that selective pressure effect is small due to limited use (Arce et al 2011). High sensitivity of piperacillin-tazobactam and cefoperazonsulbactam was possible because of their limited use, even not used in patients involved in this study (Table 3.)

The antibiotic use is not the only caused of the emergence of antimicrobial resistance. (Barbosa, 2017). There are many factors that influence resistance, such as cross-selection, spread, antibiotic residues, resistant gene transfer, infection control, patient transfer in a health institution, community mobility and socioeconomic factors (Levy 2002; Barbosa, 2017). Resistance rates in of hospitalized patients (ICU and Tropical Infection wards) were significantly different against other study about intestinal flora of the patients at Primary health center $(p<0.001)$, in whcih the use of antibiotics in Primary health center was also lower (1.6 DDD) (Dewanti, 2016). It show that the quantity use of antibiotic serve as major factor for the emerging of antimicrobial resistance. The prudent use of antibiotic has been promoted as core policy in Indonesia to suppress the use of antibiotics (Kemenkes RI, 2015).

\section{CONCLUSION}

Total use of antibiotics at Tropic Infection Ward was 137.75 DDD or 54.86 DDD/100 patient-days, and at ICU was 180.17 DDD or 68.56 DDD/100 patient-days. There was no significant difference of antibiotic use between Tropical ward and ICU $(\mathrm{p}=0.44)$. The pattern of resistant of gut flora Escherichia coli between hospitalized patients in ICU and Tropic Infection Ward also showed no significant difference $(p>0.05)$. There was not significant correlation between antibiotic use and the resistance of $E$. coli gut flora between Tropical ward and ICU. There was also not significant different of the pattern of antimicrobial resistance $E$. coli, between the user and not user of antibiotic in Tropical infection ward and ICU ward in Dr.Soetomo hospital Surabaya.

\section{REFERENCES}

AMRIN Study Group, 2005. Antimicrobial Resistance, Antibiotic Usage and Infection Control, A SelfAssessment Program For Indonesian Hospitals, Directorate of General Medical Care, Ministry of Health, Republic of Indonesia.

Arce JM, Selva M, Perpinan H, Gubernado M, Armero CC, Quilez AL, Gonzales F \& Vanaclocha H, 2011. Antimicrobial Resistance According to Age, Gender, Culture Site and Patient Location in more than 100.000 Escherichia coli. Antimicrob agent chemother; vol. 53: pp. 1222-1228

Barbosa C, Trebosc V, Kemmer C, Rosenstiel P, Beardmore R, Schulenburg H \& Jansen G, 2017. Alternative Evolutionary Paths to Bacterial Antibiotic Resistance Cause Distinct Collateral Effects. Mol Biol Evol, vol. 34, no. 9, pp. 2229-2244.

Bruinsma N, Stobberingh E \& P. de Smet, 2003. Antibiotics used and the prevalens of antibiotics resistance in bacteria from healthy volunteers in Dutch community. Infection; no. 1: pp. 9-14.

Brunton LL, Chabner BA \& Knolimam BC, 2011. Goodman and Gilman's The Pharmacological Basis of Therapeutics: Chemotherapy of Microbial Diseases, 12th edn. McGraw-Hi11; chapter 7.

Duerink DO, Lestari ES, Hadi U, Nagelkerke NJ, Severin JA, Verbrugh HA, Keuter M, Gyssens IC \& Broek PJ, 2007. Determinant of carriage of resistance Escherichia coli in the Indonesian population inside and outside hospital. J Antimicrob Chemother ; vol. 60: pp. 377-384.

Elaa M, Ferjani S, Jendoubi A, Hammami S, Hamzaoui Z, Saidani M, Houissa M, Slim A \& Dubois V, 2016. High Prevalence of Gut Microbiota Colonization with Broad-Spectrum Cephalosporin Resistant Enterobacteriaceae in a Tunisian Intensive Care Unit. Front Microbiol; vol. 7, article 1859.

Hadi U, 2009. Antibiotic usage and antimicrobial resistance in Indonesia, Doctoral thesis, Leiden University, Leiden-Netherland.

Kemenkes RI, 2015. Program Pengendalian Resistensi Antimikroba Di Rumah Sakit, Kementrian Kesehatan Republik Indonesia, Jakarta

Kuntaman K, Lestari ES, Severin JA, Kershof IM, Mertaniasih NM, Purwanta M, Hadi U, Jonhson JR, Belkum AV \& Verburgh HA, 2005. Fluoroquinolon- 
Resistant Escherichia coli, Indonesia, Emerg Infect Dis; vol. 11, no. 9: pp. 1363-1369.

Levy SB, 2002. Factors impacting on the problem of antibiotic resistance, J Antimicrob Chemother; vol 49(1): 25-30

Dewanti L, Sulistiawati, Mariatul Q, Hari P, Kuntaman K, 2016. Kajian penggunaan antibiotika dan pola resisten bakteri flora usus di Puskesmas di Surabaya. Kementrian Kesehatan Republik Indonesia, Jakarta.

Penders J, Stobberingh EE, Savelkoul PH \& Wolffs PF, 2013. The human microbiome as a reservoir of antimicrobial resistance. Front Microbiol, vol.4 pp. 87.
Pedrera V, H. Schwarz, M. Pascual de la Torre, V. GilGullen, D. Orozco, \& JM. Caselles, 2004. Analysis of Antibiotic Use in The Community of Valencia (20002002). Enferm Infect Microbiol Clin; 22: 385-389

WHO, 2012. The Evolving Threat of Antimicrobial Resistance Options for action, World Health Organization, Geneva.

WHO SEARO, 2010. Regional Strategy on Prevention and Containment of Antimicrobial Resistance 20102015, WHO South East Asian Regional Office. New Delhi, India 